\section{THE MODERN FOREIGN LANGUAGE STUDY}

$\mathrm{E}$ XTENDED research work involving a number of controlled experiments in the administration of achievement tests in modern foreign languages has been undertaken by the Modern Foreign Language Study, a research organization under the auspices of the American Council on Education. Professor Robert Herndon Fife, of Columbia University, is chairman of the Committee on Direction and Control, which has issued so far two bulletins bearing on the program of the study.

The classroom teacher of modern languages who wishes to coöoperate in this national undertaking will find presented in the following pages a general statement of the study's plans.

\section{MEASUREMENT OF ABILITY IN THE MODERN FOREIGN LANGUAGE}

An important step in the improvement of learning and teaching the modern languages is the determination of the present standards and accomplishments in school and college instruction. For this purpose it is necessary to develop and apply more adequate and objective devices for measurement than we now possess and to administer them widely. In the construction of tests personal and subjective judgments of achievement and progress must be eliminated so far as possible, and the present highly varying systems of marking results replaced by an objective system of scoring which will be easily understood and uniformly administered. Valid, reliable, and comprehensive standards of measurement are important for the establishment of norms of achievement and for making reliable comparisons. Only through such means of measurement can the effect of varying methods, abilities, ages, and conditions of instruction be lifted out of the realm of opinion and conjecture. Accurate measurement must precede intelligent dis- cussion. Such means of measurement, though applicable to all students within their range of use, do not, of course, imply any dead uniformity in the contents or methods of instruction. Indeed, their value lies in the possibility of accurate measurement for purposes of comparison of skill and capacity in language attained by the most widely divergent methods.

\section{TESTS OF LINGUISTIC ABILITY AND PROGRESS}

To determine accurately a fairly complete profile of a pupil's achievement in so complex a matter as ability in the foreign languages requires the following battery of tests:

1. A Vocabulary Test, to measure growth in vocabulary at successive stages under varying conditions and with varying methods.

2. A Silent Reading or Comprehension Test, to measure the ability to read and understand the written or printed language.

3. A Translation-into-English Test, to measure ability to render a foreign language into English.

4. A Translation Test, to measure ability to render English sentences or passages into the foreign tongue.

5. A Written Composition Test, to measure ability in free composition.

6. A Grammar Test, to measure functional knowledge of forms, syntax, and idiom.

7. A Pronunciation Test, to measure ability to enunciate correctly the sounds and words of the foreign language.

8. An Aural Comprehension Test, to measure ability to understand a foreign language when spoken.

9. An Oral Composition Test, to measure ability to speak the foreign language.

\section{THE CONSTRUCTION OF ACHIEVEMENT TESTS}

Since, with a few exceptions, such tests do not now exist, it will be necessary to construct them in the four languages concerned 
-French, German, Italian, and Spanish. For some of the capacities involved test techniques affording satisfactory models have been well worked out in English. For others, such models are altogether lacking and it is hardly possible that the Study can construct thirty-six standard tests of satisfactory character. The building of even one such test is an involved and difficult process, for experience has shown that an uncritical assembly of test items into one of the many novel forms developed in intelligence and educational testing will not result in a useful test for accurate discrimination. The steps in the construction of a standard test are clearly marked and are the following:

1. The selection of test items. In view of the diversity of texts, curricula, and methods, the materials must be analyzed critically and in detail. For example, for a Vocabulary Test a necessary condition is a knowledge of word frequency, and for a Grammar Test a tabulation of the common features in currently used grammars. In a Silent Reading Test the material must be carefully graded in difficulty with regard to vocabulary and syntax. For valid use the test must contain, especially at the early levels, only such items as those with which the students have come into contact, and new items can be progressively added only according to the same rule.

2. A preliminary grading of material by uniformly progressive steps of difficulty. This must be based on the judgment of a number of competent teachers.

3. The selection of a technique that will yield the most reliable and objective measurement. Preliminary experimentation is needed to determine the most appropriate form of technique. Among such forms are the "true-false" type; the "selection" or "multiple response" type, where the choice is to be made be- tween three, four, five, or more alternatives; the "completion" type, where blanks are to be filled in with the correct responses; the "cross-out" type, where irrelevant words or phrases are to be deleted; the "correction of errors" type, etc.

As a matter of fact, the choice of the best technique will probably vary with the purposes for which the test is administered; hence not one but several tests with different techniques are useful. For example, in a vocabulary test or in a grammar test the ability to recognize the correct word or form when it is presented as an alternative to other words or forms that are incorrect is not identical with the ability to recall the correct word or form to fill a blank. The scores by the first method will run uniformly higher than by the second. The correlations between the results of the two methods will be very high, however, so that for measuring relative achievement either method may be used. For measuring absolute achievement the functions are certainly, to some extent, independent.

4. Preliminary experiments with pupils. On the basis of these the items can be more accurately graded and the usability of the test determined with reference to clearness, reliability, length, convenience of administration, adequacy of time allowance, objectivity of scoring, etc. For this purpose it will be necessary to experiment with several hundred pupils.

When a test has been so constructed, it should have a validity for the establishment of norms of performance. Care must be taken in administration that the sampling of the school population be sufficiently wide and representative for the purpose desired, whether that be the establishment of a norm of accomplishment for the entire country, for a single state, or within a more restricted field. 
III. THE CHARACTERISTICS OF A RELIABLE STANDARD TEST OR SCALE

1. It must be valid. That is, it must measure what it purports to measure. The hopeless inadequacy of the present tests and school marks has been frequently demonstrated. An early investigation by Starch and Elliott showed that 142 teachers of English in the North Central Association of Colleges and Secondary Schools graded the same paper from 63 to 98 per cent; while the marks for a history paper ranged from 43 to 92 , and for a geometry paper from 28 to 92 . It is plain that while standard tests are as yet but imperfect measuring instruments, they are so much better than the meaningless things they are designed to replace that the development of them in all school subjects is inevitable.

2. It must be reliable, i. e., it must yield consistent results when administered to different groups or to the same group at different times. To determine reliability it is necessary to have equivalent alternative forms. Less satisfactory is the repeated application of the same test or its division into two parts by selecting the items alternatively.

3. It must be objective, i. e., the same score must be obtained by different scorers or by the same scorer at different times.

4. The directions must be brief and explicit, and easily followed.

IV. THE ADMINISTRATION OF STANDARD TESTS

These tests lose their value unless the directions which accompany them are strictly followed. The test should be given to an entire group, not to pupils especially selected by the teacher. The time limit should be rigorously observed. Even minor departures from the instructions may invalidate the results.

V. THE RESULTS OF STANDARD TESTING

When the full complement of tests is available, a literature of fact can be substi- tuted for the large literature of opinion on such controversial questions as these: The normal growth in ability to read, write, speak, or understand a foreign language by successive semesters; the effect of varying methods on the different abilities in language; the effect on achievement in various abilities which results from the age at which the study of the language is begun; the effect of varying periods of disuse on language abilities; the effect of transfer from the study of one foreign language to another; comparative achievements of pupils beginning a modern language in secondary school and in college; comparative achievements of pupils in European and in American schools; the effect of practice reading vs. practice in translation on the ability to read a foreign language, etc.

\section{PROGNOSIS TESTS}

Aptitude for achievement in foreign-language study depends, certainly, upon general intelligence, which can be measured by previous scholastic performances or by an intelligence test. It probably depends also upon certain special aptitudes peculiar to language learning. Wide interest is felt in special prognosis tests for determining aptitude for the acquisition of a foreign language. This learning is, however, a complex process involving various mental processes or factors. In constructing an aptitude test these must first be analyzed and tests devised for each of the special elements so far as they can be isolated, and a battery of tests built up. It is therefore unlikely that a single test will ever be found that will diagnose linguistic ability, though it is possible that a team of tests will be found. It should, however, be stated that the existence of a specialized aptitude for languages is not universally conceded. Several prognosis tests have been devised, but their value has not been demonstrated. From the data available it is evident that progress in a foreign language can be predicted quite as well by a general intelligence test as by 
any existing battery of prognosis tests. This important and intricate problem is being attacked vigorously by at least four groups of investigators working for the Study, more or less independently of each other, and significant results may be expected.

\section{TESTS AVAILABLE FOR ADMINISTRATION}

The Study is proceeding as rapidly as possible with the construction of tests. These will be published as fast as they are ready by the American Council on Education and the Conference of Canadian Universities. For the information of teachers there follows a bibliography of standardized tests in modern languages, so far as these have been issued or will be issued at an early date. Further lists will be sent out as the publication of tests goes forward.

School administrators and modern language teachers are urged to procure the tests and administer them as widely as possible, forwarding the scores to the office of the $S t u d y$, in order that they may be studied in connection with other material. Score sheets will be forwarded gratis from the Study office on request. The score sheet will show a column for recording the mental age of the student based on an intelligence test. Wherever this information is available or can be secured, it should be filled in.

PRELIMINARY BIBLIOGRAPHY OF MODERN FOREIGN LANGUAGE TESTS, PROGNOSIS TESTS, AND VOCABULARY STUDIES

\section{FRENCH}

Coleman, A. French Silent Reading Test: Form A. French Grammar Test: Form A. To be published by the American Council on Education.

Handschin, C. H. Handschin Modern Language Tests. Silent Reading Tests A and B: French. Comprehension and Grammar Test A: French. World Book Company, Yonkers-on-Hudson, New York; 1920.

Henmon, V. A. C. Henmon French Tests (Vocabulary, Sentence Translation). World Book Company, Yonkers-on-Hudson, New York; 1921.

French Vocabulary Tests : Forms A, B, C, D, E. Forms $\mathrm{A}$ and $\mathrm{B}$ to be published by the American Council on Education.

VAN der Beke and Stoddard, G. D. Iowa Placement Examinations in French (Vocabulary,
Grammar, Silent Reading). State University of Iowa Press, Iowa City, Iowa.

Wilkins, Lawrence A. Achievement Tests in Vocabulary, Idioms, Verbs, Grammar, Pronunciation, Comprehension, and Composition. Part I, Elementary; Part II, Advanced. Published in Supplement to Petit Journal, Doubleday, Page \& Co., Garden City, New York; February, 1924.

Wood, Ben D., Meras, Albert A., and Roth, Suzanne. Placement Test in French (Vocabulary, Comprehension, Grammar). To be published by World Book Company, Yonkers-on-Hudson, New York.

Placement Test in French (Vocabulary, Comprehension, Idioms, Translation) : Experimental Edition. World Book Company, Yonkers-onHudson, New York; 1923.

\section{SPanish}

Buchanan, M. A. Spanish Vocabulary Tests: Forms A and B. To be published by the American Council on Education.

Handschin, C. H. Silent Reading, Test A: Spanish. World Book Company, Yonkers-onHudson ,New York; 1920.

Russell, G. O. Achievement Tests in Spanish Silent Reading, Grammar, Composition, Understanding-Spoken Spanish, Pronunciation). To be published by the American Council on Education.

Van der Beke, Stondard, G. D., and Ruch, G. M. Iowa Placement Examination in Spanish (Vocabulary, Silent Reading, Grammar). State University of Iowa Press, Iowa City, Iowa.

Wilkins, Lawrence A. Achievement Tests in Vocabulary, Idioms, Verbs, Grammar, Comprehension, and Composition. Part I, Elementary; Part II, Advanced. Published as Supplement to El Eco, Doubleday, Page \& Co., Garden City, New York; February 1, 1924.

Woon, Ben D. Placement Test in Spanish (Vocabulary, Comprehension, Grammar). To be published by World Book Company, Yonkers-onHudson, New York.

\section{GERMAN}

Henmon, V. A. C. German Vocabulary Tests. Based on Kaeding's Häufigkeitswörterbuch : Forms A, B, C, D, E.) Forms A and B to be published by the American Council on Education.

Morgan, B. Q. German Grammar Test: Forms $A$. and $B$. To be published by the American Council on Education.

Purin, C. M. German Silent Reading Test: Form To be published by the American Council on Education.

Purin, C. M., and Wood, Ben D. Placement Test in German (Vocabulary, Comprehension, Grammar). To be published by the American Council on Education.

\section{Prognosis Tests}

Handschin, C. H. Predetermination Tests. Bureau of Education, Washington, D. C.

Stondard, G. D., Van der Beke, and Ruch, G. M. Iowa Prognosis Tests. State University of Iowa Press, Iowa City, Iowa. 
Wukins, Lawrence A. Prognosis Test in Modern Languages. World Book Company, Yonkers-on-Hudson, New York.

\section{Vocabulary Studies}

Buchanan, M. A. A Spanish Word Book. (Based on a count of $1,200,000$ running words.) To be published by the American Council on Education.

Henmon, V. A. C. A French Word Book. (Based on a count of 400,000 running words.) Bureau of Educational Research, University of Wisconsin, Madison, Wisconsin; September, 1924.

Morgan, B. Q., and Henmon, V. A. C. A German Word Book. (A reduction of Kaeding's Häufigkeitswörterbuch-a count of $10,000,000$ running words - to a dictionary basis.) To be published by the University of Wisconsin, Madison, Wisconsin.

\section{ENGLISH NOTES}

ENGLISH PROGRAM AT NORFOLK

$\mathrm{P}$ ROMISE of unusually interesting meetings of the English Section of the State Teachers Association is held out by the announcement of the programs at Norfolk on November 25. The hour and place of meetings will be announced in the complete program issued from the office of Secretary Heatwole.

\section{English Teachers Section}

Wednesday morning, November 25

H. Augustus Miller, Jr., Presiding

1. President's report

2. Discussion of plans for the future

3. Report of the Publication Committee.

4. Treasurer's report

5. Election of officers

Wednesday afternoon, November 25

H. Augustus Miller, Jr., Presiding

1. Some English Problems, Mrs. C. B. Bowry, Haytokah Agricultural High School, Nottoway

2. English Grammar in the High School, Professor Asa D. Watkins, HampdenSidney College

3. Social English, Mr. S. A. Martensen, Supervisor of Elementary Education, Petersburg
4. The Study of English Literature at Oxford, Professor Arthur Kyle Davis, Jr., University of Virginia

5. A Special Course in Literature for High School Seniors, Mr. T. G. Pullen, Jr., Newport News High School

\section{POETRY AT PETERSBURG HIGH}

Three sheaves of verse which appeared in the May issue of The Missile, quarterly magazine published by the students of the Petersburg High School, have received merited praise from Miss Harriet Monroe, editor of Poetry, A Magazine of Verse.

The verse was written by three seniors in the high school last session; Miss Ruth Ackerman's verses were called "Keepsakes," Miss Elizabeth Ellis's were collected under the title "Thistledown," and Miss Honoria Moomaw's were entitled "The Enchanted Realm."

Miss Monroe's comment, which appeared in the October issue of Poetry, follows :

"Although groups of poets, and magazines printing serious verse, are common in undergraduate college circles, parallel movements among high school students are rare. Of unusual interest is the May number of The Missile, printed at the town high school of Petersburg, Va. A number of these boys and girls have developed a modern technique in writing verse, and have learned to speak in an individual idiom. Since the talents of promising adolescent poets are often quickly exhausted, perhaps it would be well if young poets everywhere were encouraged to achieve their literary careers before going to college. Most of them would be sifted out, and the others would have a head start in their poetic apprenticeship."

\section{LITTLE THEATRE PROGRAMS}

That six separate little theatre organizations in Charlottesville, Lynchburg, and Richmond were active during the past year in presenting programs is disclosed in the October issue of the Little Theatre Month$l y$, published in conjunction with The 